\title{
PPID Gene
}

National Cancer Institute

\section{Source}

National Cancer Institute. PPID Gene. NCI Thesaurus. Code C118130.

This gene plays a role in the catalysis of protein folding. 